\title{
The Role of Monetary and Macroprudential Policy Instruments on Macroeconomic Stability in Southeast Asian Countries
}

\author{
Eka Febrianti Utami ${ }^{1, *}$ \\ ${ }^{1}$ Department of Economics and Development Studies, University of Jember, Jember, Indonesia. \\ *Corresponding author.Email: ekafu2002@gmail.com
}

\begin{abstract}
The impact and trauma of global financial crisis overshadowed the post-crisis economic recovery in the last two decades. Monetary and macroprudential policies are the two most popular and general policies to maintain macroeconomic stability. Covid-19 has become a storm in the economy, paralyzing the economic conjuncture and not promising positive economic growth. Two steps of economic recovery can be used as an alternative interpretation of economic recovery due to the financial crisis, namely point of view of Smets and New Triffin Dilemma. The estimation of Panel Ordinary Least Square (POLS) in 5 ASEAN countries shows that monetary policy plays a more dominant role in shaping macroeconomic stability. The variables of trade and foreign capital flows which are part of the New Triffin Dilemma, namely FDI, have no significant effect on macroeconomic stability. Meanwhile, the exchange rate and inflation rate have a significant impact on the formation of macroeconomic stability. The overall results of this study conclude that the Smets point of view that separates the roles of monetary and macroprudential policy on macroeconomic stability is considered better in supporting the realization of macroeconomic stability. At the same time, the New Triffin Dilemma can be role as a supporting policy.
\end{abstract}

Keywords: Global financial crisis, macroeconomic stability, macroprudential policy, monetary policy, new triffin dilemma.

\section{INTRODUCTION}

The trauma of the 2008/2009 financial crisis on the world economy inspired researchers to make a breakthrough. Through an in-depth empirical and theoretical review of the crisis, the impact and consequences of the 2008/2009 financial crisis can be divided into four: global economic instability, the vulnerability of the domestic economy, increased unemployment, and high public debt risk [1]. Several changes of the 2008/2009 financial crisis have indirectly recorded several forms of trauma due to the crisis, namely the decreased public enthusiasm for taking housing loans and other types of credit that have asset value.

In 2010, Daniela Magalhães Prates and Marcos Antonio Macedo Cintra conducted a study on the impact of the 2008/2009 financial crisis on financial markets in developing countries [2]. His research shows emerging market economic strategies after the financial crisis is insufficient to immunize systemic finance risks. Although implementing prudent macroeconomic policies and the maximum accumulation of foreign currency reserves, adopting appropriate instruments for managing capital flows through monetary and macroprudential policies with dual mandates is urgently needed.

In China, Laike Yang and Cornelius Huizenga proved that the 2008/2009 financial crisis caused a dramatic decline in foreign trade, direct investment, unemployment, and substantial price fluctuations [2]. In India, the 2008/2009 financial crisis has hampered economic growth [3],[4],[5]. The increase in trade and financial traffic in the country that became the epicenter of the crisis led to a sharp decline in growth. Brazil faced a more significant impact from the $2008 / 2009$ financial crisis than India. In 2009, the Brazilian economy fell into recession and recorded a real GDP contraction of $-0.2 \%$ compared to India's real GDP, which grew at 6\% in April 2009 - March 2010. This remarkable performance shows that India is the 
second least affected by the global financial crisis after China. The monetary and fiscal policy response to the financial crisis was broader than that of Brazil in rescuing the economy from recession.

The Southeast Asian economy has entered its worst recession since the 2008/2009 global financial crisis. The region needs the right policy tools to restore its economy. Rasiah, Yap, and Chandran, in 2014, researched the primary export support industries, namely Singapore, Malaysia, Indonesia, Thailand, and the Philippines [6]. They argue that the financial crisis affected exports in these countries. Doner and Wad, in 2014, also argued that the financial crisis affected the industrial sector [7]. In Thailand, the crisis accelerated the movement towards exports and played down a severe increase of risks [8]. Meanwhile, in Malaysia, the crisis did not encourage the development of a more perfectionist industry. Compared to other countries in Asia and outside Asia, countries in Southeast Asia are more resilient in recovering sectors and maintaining growth rates from the impact of the 2008/2009 global financial crisis [9].

An alternative interpretation of the impact and trauma of the 2008/2009 global financial crisis from Jan Priewe's research shows that the 2008/2009 financial crisis caused global imbalances, especially in trade and cross-border capital flows, known as the "New Triffin Dilemma" [2]. Priewe believes that the dilemma associated with the current shortage of the global currency system causes enormous income inequality and reduces aggregate demand, thereby contributing significantly to macroeconomic instability, namely financial instability and global imbalances.

In contrast to the results of Priewe's research, Frank Smets in 2014 found a new perspective, namely that the source of financial instability and global instability in the financial crisis was motivated by instability in the financial system [2]. The neglect of the objective of controlling financial system stability gave birth to a new policy, namely macroprudential policy, as a particular policy to handle and maintain financial system stability [10]. Smets said that collapse in financial markets and recovery in economic and domestic markets as a whole could use three policy points of view to control and maintain macroeconomic stability; namely, the modification of the Jackson Hole consensus, leaning against the wind, and financial stability is price stability [11]. Each of the three policy perspectives collaborates and separates two forms of policy such as monetary and macroprudential policies to achieve the dual mandate of financial stability and price stability, as conceptualized by Smets in his research journal.

Utami in 2020 conducted a third study of Smet's policy perspectives in one of the developing countries, namely Indonesia [12]. The results of Utami's research stated that the Jackson Hole modification was more dominantly applied in Indonesia than the other two points of view. By using data on interest rates, inflation rates, money supply, non-performing loans (NPL), the number of property loans, and debt to income in national banks, it shows that the variable response and forecasting the impact of each variable in ten periods meet the inflation safe limit standard. and the safe ratio limit determined by the central bank.

Several empirical studies are similar to those of Smets and Utami. Using the topic of risk management and the application of monetary and macroprudential policies for dual mandates, Collard et al., in 2017, developed a model that supports the consensus modified view of Jackson hole [13]. Research Collard et al. linking excessive risk-taking and a level of risk that crisis may not reflect in the large volume of credit. In contrast to Gelain et al. in 2012, states that shortterm interest rates significantly impact inflation [14]. Mutia in 2019 found that financial system stability variables such as non-performing loans and property loans did not have a significant relationship, but there were other variables such as GDP that influenced the formation of macroeconomic stability after the global financial crisis [15].

Based on the presentation of the study of the impact of the financial crisis in Asian countries, Southeast Asia, and countries outside Asia, the discovery of a new approach in the form of the "New Triffin Dilemma" and three methods from Smets in 2014 it can be concluded that currently countries in the world, especially countries in the Asian region The Southeast needs the suitable policy instruments to save the economy from the still-warming crisis, namely the COVID-19 crisis and accelerate the success of economic recovery after the 2008/2009 financial crisis. With the latest type of economic crisis that is still active today, the ability to develop a policy framework as a spearhead and shield for mitigation is a possible step. By taking a new approach, namely the approach of Smets, the researcher aims to examine the role of macroeconomic policy instruments in realizing macroeconomic stability in Southeast Asian countries.

This paper bases the concept and research directions that have been extended from Utami's research in 2020 and Priewe's research in 2014. 
Utami's study concludes that one of Smets' perspectives is more suitable for application in developing countries such as Indonesia than the other two types of viewpoints. Priewe in 2014 added that to the post-crisis economic recovery, it is essential to control the "New Triffin Dilemma" as a critical step. As is well known today, the struggle to stabilize the economy continues. The recovery period after the $2008 / 2009$ financial crisis is not as intense as ten years ago. However, the new crisis period, namely the COVID-19 crisis, presents unique challenges for countries' economies to improve the economic sector amid large-scale social restrictions. The condition of the COVID-19 crisis is almost the same as during the 2008/2009 global financial crisis, where a significant shock occurred when economic conditions were within safe limits. It's just that there is a striking difference where the source of the 2008 financial crisis is the capital market, while the COVID-19 turmoil is due to a virus/health side that limits the interaction of economic actors so that it has a systematic effect on the macroeconomic sector. Based on comparing two different forms of crisis and the existence of new alternative perspectives on crisis recovery, in this paper, the researcher will compare two types of alternative viewpoints, namely the "New Triffin Dilemma" from Priewe and the policy instrument point of view from Smets. It aims to determine the appropriate policy approach in achieving economic stability through the application of monetary and macroprudential policy instruments.

\section{METHODOLOGY}

Southeast Asia is one of the regions with the most developing countries compared to the other five regions in Asia. In fact, with the existence of the ASEAN association organization, the economies of the countries that are members of it get more benefits, such as economic regulations that improve the welfare of the region. Therefore, researchers chose countries that are members of ASEAN as research samples.

To make it easier to conclude, the researchers of this paper divide the members of ASEAN based on two geographical conditions, namely insular and the mainland. In countries classified as riding economies, two sectors, namely agriculture, and marine, called insular, namely Indonesia, Malaysia, Singapore, the Philippines, and Brunei Darussalam, were chosen as research samples. Insular countries in Southeast Asia were selected as research samples because economic conditions and reflection of policy implementation are faster and more visible than mainland countries which only rely on one agricultural sector as the backbone of their economy.

Meanwhile, the data used in this study were sourced from the online publications of the World Bank, Trading Economics, Fred Statistics, and CEIC Data.

The 2010 - 2020 annual panel data research used the Panel Ordinary Least Square (POLS) method. The adoption of the general POLS model from Caecilia Wahyu E.R in 2008 and Nugroho, Purnama, and Fauzia in 2018 in this study is written as follows [16],[17]:

$G D P_{i t}=\beta_{1}+\beta_{2} I N F_{i t}+\beta_{3} K U R S_{i t}+\beta_{4} N P L_{i t}+$ $\beta_{5} R R_{i t}+\beta_{6} F D I_{i t}+\mu_{i t}$

From equation (1), the ordinary least square panel model for the Smets point of view is written as follows:

$G D P_{i t}=\beta_{1}+\beta_{2} I N F_{i t}+\beta_{3} K U R S_{i t}+\beta_{4} N P L_{i t}+$ $\beta_{5} R R_{i t}+\mu_{i t}$

Meanwhile, the ordinary least square panel model for the New Triffin Dilemma is written as follows:

$G D P_{i t}=\beta_{1}+\beta_{2} K U R S_{i t}+\beta_{3} F D I_{i t}+\mu_{i t}$

Where $G D P_{i t}$ is the total gross domestic product of country $\mathrm{i}$ in period $\mathrm{t}, I N F_{i t}$ is the sum of the inflation rates of country $\mathrm{i}$ in period $\mathrm{t}, K U R S_{i t}$ is the total exchange rate of country $\mathrm{i}$ in period $\mathrm{t}, N P L_{i t}$ is the total non-performing loan ratio of country $\mathrm{i}$ in period $\mathrm{t}, R R_{i t}$ is the reserve requirement of state bank $\mathrm{i}$ in period t, $F D I_{i t}$ is the amount of foreign investment in country $\mathrm{i}$ in period $\mathrm{t}, \mu_{i t}$ is disturbance error, $\mathrm{i}$ is $1,2, \ldots . ., 5, \mathrm{t}$ is $1,2,3,4,5,6$

This regression model will be estimated using an approach that uses dummy variables, namely the fixed effect model and the random effect model, but previously used the ordinary least square method. This is intended so that the estimation results of each approach can provide the best regression model from this test.

\section{RESULTS AND DISCUSSION}

The following summarizes the test results of each policy variable for the entire sample of 5 selected countries during the ten-year observation period in the statistical table (table 1). 
Table 1. Descriptive Statistics

\begin{tabular}{|l|l|l|l|l|l|l|}
\hline & GDP & INF & KURS & NPL & RR & FDI \\
\hline Mean & 22259.86 & 2.37 & 12993.96 & 2.44 & 20.38 & 3.56 \\
\hline Median & 10608.41 & 2.02 & 3586.50 & 2.01500 & 20.09 & 2.09 \\
\hline Maximum & 66188.78 & 20.181 & 52661.00 & 6.86 & 45.63 & 9.94 \\
\hline Minimum & 2217.47 & -17.61 & 1249.000 & 0.75 & 5.50 & -1.51 \\
\hline Std. Dev. & 22214.04 & 5.64 & 17518.75 & 1.37 & 8.78 & 3.28 \\
\hline Skewness & 0.70 & 0.10 & 1.34 & 1.35 & 0.52 & 0.60 \\
\hline Kurtosis & 1.88 & 7.31 & 3.108 & 4.37 & 2.86 & 1.92 \\
\hline Jarque-Bera & 6.76 & 38.8 & 15.10 & 19.17 & 2.37 & 5.42 \\
\hline Probability & 0.03 & 0.00 & 0.004 & 0.09 & 0.30 & 0.06 \\
\hline Sum & 1112993. & 118.93 & 649698.0 & 122.30 & 1019.06 & 1.78 \\
\hline Sum Sq. Dev. & 2.40 & 1561.61 & 1.50 & 92.40 & 3780.64 & 5.28 \\
\hline Observations & 50 & 50 & 50 & 50 & 50 & 50 \\
\hline Cross Sections & 5 & 5 & 5 & 5 & 5 & 5 \\
\hline
\end{tabular}

\subsection{Hypothesis Test}

\subsubsection{Stationary Test}

Before testing the hypothesis, which states that macroeconomic stability (proxied by gross domestic product (GDP) is influenced by inflation rates, exchange rates, non-performing loans (NPL), and reserve requirements. Macroeconomic stability is also affected by foreign domestic inflows (FDI). Significant research variables from the static test are data stability tests that can use for forecasting. The results are seen in table 2.

Table 2. Stationary Test based on Levin, Lin and Chu method

\begin{tabular}{|c|c|c|c|c|}
\hline Variabel & Statistic & Prob* & $\begin{array}{c}\text { Cross- } \\
\text { sections }\end{array}$ & Obs \\
\hline GDP & -1.15712 & 0.0123 & 5 & 40 \\
\hline INF & -4.16062 & 0.0000 & 5 & 40 \\
\hline KURS & -1.72363 & 0.0424 & 5 & 40 \\
\hline RR & -9.95046 & 0.0000 & 5 & 40 \\
\hline NPL & -6.59899 & 0.0000 & 5 & 40 \\
\hline FDI & -4.65864 & 0.0000 & 5 & 40 \\
\hline
\end{tabular}

Note: * = Levin, Chu \& Chu test probability assumed normality

Based on the test results using the Levin, Chu \& Chu method noted that the stationary data test is significant. There is no unit root for the six variables (GDP, INF, EXCHANGE, RR, NPL, and FDI), or the data is stationary. Thus, this research can continue the next step.

\subsection{Choosing the Best Policy Regression Model from the Viewpoint of Smets and the New Triffin Dilemma}

The first model used is the OLS approach, where the common intercept and the standard coefficient are used to estimate the panel data. The OLS model is feasible if the constants or intercepts are the same for all countries. Furthermore, for the second and third models, there are fixed effects and random effects, respectively. Both OLS models are used if there is no significance in the first model.

The tests using panel ordinary least square (POLS) in this paper uses three OLS models: common, fixed, and random. The resulting test found that the best model used to conclude variable responses from the Smets point of view was the fixed effect model.

Complaints determine the best model is to use the likelihood ratio test. This test states that the test probability is 0.0000 (smaller than the 0.05 significance level), which means the fixed effect chose as the best model. After getting the results of the likelihood ratio test, the next step is to test the random effect using the Hausman test. This test concludes that there is a significant correlation. Therefore, the best regression model for Smets' point of view is the OLS regression model using random effects. Meanwhile, the test results can be seen in table 3 . 
Table 3. Best OLS Model Testing Results using E-Views 10

\begin{tabular}{|c|c|c|}
\hline \multicolumn{3}{|c|}{ OLS MODEL } \\
\hline \multicolumn{3}{|c|}{ Smets Viewpoint } \\
\hline \multicolumn{3}{|c|}{ GDP c INF KURS NPL RR } \\
\hline $\begin{array}{l}\text { Redundant Fixed Effects - } \\
\text { Likelihood Ratio }\end{array}$ & $\begin{array}{c}\text { Pmmited Random Effects - Lagrange } \\
\text { Multiplier }\end{array}$ & $\begin{array}{c}\text { Correlated Random Effect - } \\
\text { Haustman Test }\end{array}$ \\
\hline 0.0000 & Not Available & $0.0000^{* *}$ \\
\hline \multicolumn{3}{|c|}{ New Triffin Dilemma } \\
\hline \multicolumn{3}{|c|}{ GDP c KURS FDI } \\
\hline $\begin{array}{l}\text { Redundant Fixed Effects - } \\
\text { Likelihood Ratio }\end{array}$ & $\begin{array}{c}\text { Pmmited Random Effects - Lagrange } \\
\text { Multiplier }\end{array}$ & $\begin{array}{c}\text { Correlated Random Effect - } \\
\text { Haustman Test }\end{array}$ \\
\hline $0.0000^{* *}$ & Not Available & Not Available \\
\hline
\end{tabular}

\subsection{Estimation Results of Panel Tests on Policy Variables in the Perspective of Smets and the New Triffin Dilemma}

Testing the best OLS model for an alternative point of view linking trade planes and foreign model flows (the new triffin dilemma) falls on the likelihood ratio or what is usually said to be significant on the fixed effect. Based on the test results in table 3, the variables contained in the new triffin dilemma also impact achieving macroeconomic stability. At the same time, the test results can be seen in table 4 . regulations in the market that encourage economic policymakers to limit the number of incoming funds, for example, financial products from financial markets that quickly lose their liquidity. More striking result significance from New Triffin Dilemma variable obtained from the estimation results from the point of view of Smets. Meanwhile, macroeconomic stability and variable policy can show the results of the research in Table 5.

The role of monetary and macroprudential policy variables has a more transparent effect than the new triffin dilemma variable. Viewpoint Smets found two

Table 4. New Triffin Dilemma Data Panel Estimation Results: Redundant Fixed Effects - Likelihood Ratio

\begin{tabular}{|l|l|l|l|l|}
\hline Variabel & Coefficient & Std. Error & t-statistic & Prob. \\
\hline C & 29810.27 & 4066.364 & 7.330940 & $0.0000^{*}$ \\
\hline KURS & -0.759329 & 0.152487 & -4.979644 & $0.0000^{*}$ \\
\hline FDI & 6.511210 & 8.138210 & 0.799820 & 0.4278 \\
\hline \multicolumn{4}{|c|}{ Effect Specification Cross-section } \\
\hline R-squared & 0.346040 & F-statistic & 12.43494 \\
\hline $\begin{array}{l}\text { Adjusted } \\
\text { R-Squared }\end{array}$ & 0.318212 & Prob(F-statistic) & 0.000046 \\
\cline { 1 - 2 } $\begin{array}{l}\text { Durbin-Watson } \\
\text { stat }\end{array}$ & 0.045664 & \\
\hline
\end{tabular}

Judging from the estimation results of the POLS test for the New Triffin Dilemma, monetary policy, namely the exchange rate, had a significant effect on macroeconomic stability in five countries. Meanwhile, in terms of trade and foreign capital flows represented by foreign direct investment (FDI), these variables did not affect macroeconomic stability. This condition provides a new reflection of the situation that the level of investment and inflows of funds in ASEAN countries is lower than outflows. Weak financial markets in developing countries cause imbalance and a smaller influx of funds into ASEAN countries. Regulations that have been updated quickly in less than five years are due to changes in the domestic economy. The changes in the domestic economy, such as declining consumption and the existence of new complete results. First, the POLS results from Smets conclude that monetary policy variables except NPL affect the formation of macroeconomic stability in five ASEAN countries. Second, the POLS results also conclude that the first Smets view that separates monetary and macroprudential policies with the same objective applies to the five ASEAN countries. This conclusion comes from the estimation results in table 5 below.

The study results using the panel estimation results in Tables 4 and 5 can be concluded in general that macroeconomic policies, namely monetary policy and macroprudential policies, have a significant effect on the formation of macroeconomic stability in ASEAN. 
Table 5. Smets Viewpoint Data Panel Estimation Results: Redundant Fixed Effects - Likelihood Ratio

\begin{tabular}{|l|l|l|l|l|}
\hline Variabel & Coefficient & Std. Error & t-statistic & Prob. \\
\hline C & 26499.47 & 2393.765 & 11.07020 & $0.0000^{*}$ \\
\hline INF & -482.6529 & 106.6383 & -4.526073 & $0.0000^{*}$ \\
\hline KURS & -0.837962 & 0.042675 & -19.63584 & $0.0000^{*}$ \\
\hline NPL & 166.5524 & 480.0361 & 0.346958 & 0.7302 \\
\hline RR & 362.5680 & 92.86857 & 3.904097 & $0.0003^{*}$ \\
\hline \multicolumn{5}{|l|}{ Effect Specification Cross-section } \\
\hline R-squared
\end{tabular}

Monetary policy reacted more strongly than the other side, namely macroprudential policy. It cannot be denied that the exchange rate holds greater control as a variable that influences the formation of macroeconomic stability. Following the central bank's mandate, it is vital to maintain the selling and buying value of the domestic currency in each country to minimize the impact and impact of domestic shocks. The five selected ASEAN countries do not want to repeat the 1997/1998 crisis period, which suppressed the economy which eroded their foreign exchange reserves.

The dominance of monetary policy in ASEAN countries compared to macroprudential policy concludes that it is true that the Smets point of view is more suitable for use in ASEAN countries after the 2008/2009 financial crisis. Trauma recovery after the $2008 / 2009$ financial crisis in the five countries has its version by the mandate and regulations of the central bank. Suppose the Philippines and Singapore use purely monetary policy to maintain the economy and restore the economy of post-crisis countries by setting interest rates and various policy regulations in the market. In that case, there is a possibility in the other three countries, namely Indonesia, Malaysia, and Brunei Darussalam, to use more complex monetary policy ingredients to regulate conventional banks. And sharia. These three Muslim-majority countries provide a prominent place for more difficult economic policies to build the economy and maintain its stability. For now, we will ignore monetary policy for conventional and sharia because this paper's main objective is to find out the appropriate alternative policy forms for the establishment of macroeconomic stability in ASEAN countries. Perhaps, at another time and for further research, the topic can be reviewed and raised.

Knowing the dominance of monetary policy compared to macroprudential is evidenced by the significant effect of the exchange rate variable compared to the NPL, which has so far been a form of illustration of financial market conditions. In that case, apart from NPL, there are reserve requirements which are a form of backup. Backup from reserve requirements measures to find out that banking reserves do not significantly affect financial stability. This evidence that macroprudential are identical twins who maintain monetary policy when conditions or economic transformation cannot be resolve by monetary policy.

Taking care of each other and being connected, monetary policy and macroprudential policy support the workings of the Smets point of view. In the concept of Smets' point of view, the workings of monetary and macroprudential policy divide into three ways. First, namely monetary and macroprudential policies, which are separate but in line and mutually supported. Second, monetary and macroprudential policies are mixed. Finally, monetary and macroprudential policies integrated and merged into one. One (it makes no difference if the monetary or macroprudential policy variables are all used in equal proportions in the two policy forms). Monetary policy is more dominant than macroprudential; it is clear, this estimation result belongs to Smets' point of view. The alternative approach for economic recovery after the 2008/2009 financial crisis is Smets' point of view.

Some readers may wonder how Smets' point of view is essential and chosen in such a way when there is a more modern New Dilemma Triffin. Not bad and deserve to be the subject of discussion. Based on the ASEAN economic conditions, the implementation of ITF, monetary and macroprudential policies have lined up in a country's economy in recent years. This condition that has succeeded in returning the economy to a better state is the right reason for improving the domestic economic sector and conjuncture in the goods and human resources markets. More important than improving in financial markets. Financial markets in developing countries such as specific places and specifically for foreign and domestic investors to 
sell/buy securities and get a return yield per certain period. Like in a party hall, the financial market is a VIP room for special guests, while the goods market and human resources market is a standard room containing dozens of guests. From a simple example of how to place a policy position in the two existing alternative policy versions. That version concludes policymakers should pay attention to the general guest because angry protests will fill their suggestion box if they do not get a certain level of satisfaction. Managing these available guests is more complicated than working VIP guests because they can sometimes break the rules without realizing it. Like civil society consuming massive amounts of food in times of crisis or traveling out of town even though there is an explicit ban from the government during the COVID19 period.

The alternative policy New Triifin Dilemma applies in ASEAN countries with various notes. Economic conditions must be prime, inflation within safe limits, NPL within safe limits, sufficient CAR and adequate RR, and significant enough foreign exchange reserves. If all these records are complete, New Triffin Dilemma can implement. If we maximize the New Triffin Dilemma and the still-active Smets point of view, the financial market will be more active. In this condition, when the financial market is involved, the Policy package must prepare the policy version from Smets' point of view. Monetary and macroprudential policy can be role as a with its policy umbrella. It should the financial market overheat at any time.

The trauma recovery process from the 2008/2009 financial crisis was following by another crisis period, which is COVID-19. Management must handle the latest form of a crisis originating from health, creeping into the economic sector, and finally pushing the recession valleys in this cycle with patience and calm. Policymakers cannot incorporate a high dose of policy to accelerate recovery and encourage large consumption in a short period. It was like a daydream.

The Smets point of view or the New Triffin Dilemma, which policy is better to restore the economy. Neither of these alternative points of view is appropriate to drive policy. Although it is impossible to determine which one is the best in dealing with this COVID-9 period, a quick answer can ease the reader's curiosity. The answer is to maintain the inflation rate and strengthen foreign exchange reserves through monetary policy. This is used as capital if the economy suddenly becomes unfriendly to the policies currently being implemented. Regardless of the stable condition of the domestic financial market in ASEAN still apply the supervision of the financial services authority, the central bank, and macroprudential policies.

\section{CONCLUSION}

Whether New Triffin Dilemma or Smets' view is the best and the fastest in shaping economic stability. It is essential to know that monetary and macroprudential policies are two forms of policy that continue to synergize. If monetary policy encourages economic conjuncture, macroprudential encourages financial markets to be more stable by reducing financial risk through countercyclical policies. The emergence of alternative viewpoints for monetary and macroprudential policies after the crisis provided an avenue for them to continue to transform and adapt over time to conditions. In the new era after the $2008 / 2009$ financial crisis, Smets' policy point of view is more advanced and is predicted to be more influential in shaping macro-economic stability. Following developments simultaneously, the New Triffin Dilemma was developed to provide an alternative economic recovery through finance and trade. The COVID-19 period appeared in the last two years, in the range of 2020-2021, as a financial stumbling block that hindered macroeconomic recovery. During the COVID-19 period, macroeconomic stability was well maintained in ASEAN from Smets' point of view. However, it is necessary to watch out for other unexpected economic shocks such as waves of unemployment, exchange rate movements, and investment flows. However, the results of this paper indicate that Smets' view is more suitable as an alternative post-crisis and economic recovery amid the COVID-19 crisis that is still hitting today. The New Triffin Dilemma needs to be another way to support faster finance and trade in supporting macroeconomic stability.

\section{REFERENCES}

[1] I. Islam and S. Verick, "The great recession of 2008-09: Causes, consequences and policy responses," In From the Great Recession to Labour Market Recovery: Issues, Evidence and Policy Options., pp. 19-52, 2010, https://doi.org/10.1057/97802 30295186.

[2] S. Dullien, D. J. Kotte, A. Marquez, and J. Priewe. The Financial and Economic Crisis of 2008-2009 and Developping Countries. New York \& Geneva: United Nations, 2010.

[3] M. Joseph, "Global Financial Crisis: How was India Impacted?," Prepared for presentation to InWEnt-DIE Conference on Global Financial 
Governance - Challenges and Regional Responses., no. 17, 2009.

[4] S. Mehrotra, "India and the global economic crisis," Journal of Asian Public Policy., vol. 3, no. 2, pp. 122-134, 2010, https://doi.org/10.1080/17516234.2010.504326.

[5] M. Edey, "The Global Financial Crisis and Its Effects*," Economic Papers., vol. 28, no. 3, pp. 186-195, 2009, https://doi.org/10.1111/j.17593441.2009.00032.

[6] R. Rasiah, K. C. Cheong, and R. Doner, "Southeast Asia and the Asian and global financial crises," Journal of Contemporary Asia., vol. 44, no. 4, pp. 572-580, 2014, https://doi.org/10.1080/00472336.2014.933062.

[7] R. F. Doner and P. Wad, "Financial crises and automotive industry development in Southeast Asia," Journal of Contemporary Asia., vol. 44, no. 4, pp. 664-687, 2014, https://doi.org/10.1080/00472336.2014.923635.

[8] O. Notta and A. Vlachvei, "The Impact of Financial Crisis on Firm Performance in Case of Greek Food Manufacturing Firms," Procedia Economics and Finance., vol. 14, pp. 454-460, 2014, https://doi.org/10.1016/s22125671(14)00734-5.

[9] H. A. Lee and R. E. Ofreneo, "From asian to global financial crisis: Recovery amidst expanding labour precarity," Journal of Contemporary Asia., vol. 44, no. 4, pp. 688-710, 2014, https://doi.org/10.1080/00472336. 2014.931035

[10] S. Fahr and J. Fell, "Macroprudential policy closing the financial stability gap," Journal of Financial Regulation and Compliance., vol. 25, no. 4, pp. 334-359, 2017, https://doi.org/10.1108/JFRC-03-2017-0037.
[11] F. Smets, "Financial stability and monetary policy: How closely interlinked?," International Journal of Central Banking., vol. 10, no. 2, pp. 263-300, 2014.

[12] E. F. Utami. "Efektifitas instrumen kebijakan moneter dan makroprudensial terhadap stabilitas makroekonomi di Indonesia," Thesis, Department of Economic Development, Faculty of Economics and Business, University of Jember, East Java, 2020.

[13] F. Collard, H. Dellas, B. Diba, and O. Loisel, "Optimal Monetary and Prudential Policies," American Economic Journal: Macroeconomics., vol. 9, no. 1, pp. 40-87, 2017.

[14] P. Gelain, K. J. Lansing, C. Mendicino, and N. Bank, "House Prices, Credit Growth, and Excess Volatility: Implications for Monetary and Macroprudential Policy," Forthcoming, International Journal of Central Banking, Norges Bank Working Paper., no. 8, pp. 219276, 2013.

[15] A. Muthia, "Kajian Kebijakan Makroprudensial Loan to Value Ratio dalam Pengendalian Kredit Pemilikan Rumah," Jurnal Ilmu Ekonomi Terapan., vol. 4, no. 1, 2019, https://doi.org/10.20473/jiet.v4i1 11915.

[16] C. W. ER, “Ordinary Least Square vs Fixed Effect Regression Model: Studi Empirik Determinan Kebijakan Dividen pada Perusahaan-Perusahaan yang Terdaftar di Bursa Efek Indonesia (BEI)," Sinergi., vol. 10, no. 2, pp 157-169, 2008, https://doi.org/10.20885/sinergi.vol10.iss2.art6.

[17] A. A. Nugroho, M. Y. I. Purnama, and L. R. Fauzia, "Monetary Policy and the Housing Market in Indonesia: Evidence from Selected Regions," Jurnal Keuangan dan Perbankan., vol. 22, no. 4, 2018, https://doi.org/10.26905/jkdp.v22i4.2515. 